\title{
Antimicrobial Activity of Costus Plant Extract Against Methicillin-Resistant Staphylococcus aureus (MRSA, $\mathrm{I}_{3}$ )
}

\author{
Sidkey, Nagwa M. ${ }^{1}$, Aytah, Ameera A. ${ }^{2}$, Al-Ahmadi, Hind A. ${ }^{3}$ \\ ${ }^{1}$ Botany \& Microbiology Department, Faculty of Science, Al Azhar University, Cairo, Egypt \\ ${ }^{2,3}$ Biology Department, Faculty of Science, Taibah University, KSA
}

\begin{abstract}
In the present investigation, a trial was carried out to find biological active agents isolated from Costus speciosus to control the resistance that pathogenic microorganisms build against antibiotics. The rhizomes of two costus varieties viz. Qust Hindi and Qust Bahri were carried out. Costus speciosus were dried, grinded and extracted with methanol and water. The extracts were tested for their antimicrobial activities against MRSA, $I_{3}$, E.coli, $I_{5}$ and Candida albicans isolated from King Fahd Hospital, Al Madinah Al Munawarah, KSA. The aqueous extract of Qust Hindi was more effective compared with methanolic extract and aquous extract of Qust Bahri against MRSA, $I_{3} \&$ E.coli, $I_{5}$. Candida albicans was resistant to all plant extracts. Some parameters controlling the activity of this aqueous extract had been studied against pathogenic microorganisms under study. The highest antimicrobial activity obtained at the following conditions: $121{ }^{\circ} \mathrm{C}$; $\mathrm{pH}$ 5; shaking at light conditions; $200 \mathrm{rpm}$ (48 h); lactose (1\%); non of nitrogen sources; cysteine; non of metallic ions; ascorbic acid (100ppm). Treatment of coleoptiles sections with crude Costus speciosus extract exhibited 20\% of straight growth of Hordeum vulgaris coleoptiles. Among all the tested solvent systems, ethyl acetate was found the best solvent for extraction of the antimicrobial substance. Fractions 3, 4, 5, 6, 7, 8 \&9 obtained from column chromatography exhibited the highest antimicrobial activity against MRSA, $I_{3}$. TLC plates showed only two colored fractions, fraction I showed pale yellow under normal lab light, and pale fluorescent turquoise color under long wave length, and fraction II gave dark yellow under both normal and long wave length. Fraction I and fraction II gave antimicrobial activity of 25.5 and 16.25mm, respectively against MRSA, $I_{3}$.
\end{abstract}

Keywords: Costus speciosus, Qust Hindi, Qust Bahri, MRSA, E.coli, Candida albicans

\section{Introduction}

Phytochemicals with biological activity have had great utility as pharmaceuticals. Through the $19^{\text {th }}$ century and into the first half of the 20th century, the primary strategy was to discover of plant compounds and determining the active ingredients of plants (Duke, 1991; Pachlatko, 1998).

In fact, individual plant species may contain over one thousand chemical substances and only a minor fraction of the estimated total of 250,000 to 300,000 plant species has been studied for biomedical application (Tringali, 2001).

The need for new and useful compounds is ever-growing. Drug resistance in bacteria, the appearance of new lifethreatening viruses, the recurrent problems of diseases in persons with organ transplants, and the tremendous increase in the incidence of fungal infections in the world's population all underscore our inadequacy to cope with these medical problems (Kayaser and Quax, 2007).

Multiple drug resistance has developed due to indiscriminate use of existing antimicrobial drugs in the treatment of infectious diseases (Service, 1995). In addition to this, antibiotics are sometimes associated with adverse effects. Therefore, there is a need to develop alternative antimicrobial drugs for the treatment of the infectious diseases from other plant resources (Cordell, 2000).

Moreover, much attention has been paid to extracts biologically active compounds from plant species (Essawi and Srour, 2000). The use of herbal preparations made from medicinal plants is widespread in developing countries (Okpuzor and Oloyede, 2009). The healing powers of traditional herbal medicines have been realized and about $65 \%$ of the world populations have access to local medicinal plant knowledge system (Tag et al., 2007).

However, Jigna et al. (2005) support the folkloric usage of the medicinal plants and suggest that, some of the plant extracts possess compounds with antimicrobial properties that can be further explored for antimicrobial activity.

Hazrat Anas Bin Malik narrates that Rasool Allah (saw) stated "Out of those things which are being used by you for treatment, the cupping and Qust Bahri are the best treatment." (Bukhari) ${ }^{\mathbf{1}}$. Narrated Um Qais: I went to Allah's Apostle along with a son of mine whose palate and tonsils I had pressed with my finger as a treatment for a (throat and tonsil) disease. The Prophet said, "Why do you pain your children by pressing their throats! Use Ud Al-Hindi (certain Indian incense) for it cures seven diseases, one of which is pleurisy. It is used as a snuff for treating throat and tonsil disease and it is inserted into one side of the mouth of one suffering from pleurisy." (Bukhari )

Kust, Qust or costus root is the dried rhizome of Costus speciosus (Hansel et al., 1994). The plant of Qust, which is known as costus is 2-2.7 meter in length. It is generally found in the marshy and wet places along the rivers at the heights up to $5000 \mathrm{fts}$. These plants are found extensively in north west and north east sub Himalayan regions along the course of rivers. Plant roots are being used for medicinal 


\section{International Journal of Science and Research (IJSR) \\ ISSN (Online): 2319-7064}

Index Copernicus Value (2013): 6.14 | Impact Factor (2014): 5.611

purpose (Mandal, 2007; Anonymous, 2007; Gupta et al., 2008; Khan, 2009).

About 150 species of Costus speciosus (Koen.) Sm. (family: Costaceae) have been reported from the tropical regions of the world (Deb, 1983). The rhizomes are useful in curing ailments like burning sensation, constipation, fever, inflammation, worm infection and diseases like leprosy, asthma, bronchitis and anaemia (Mandal, 2007).

Traditionally, Costus rhizomes are indicated in the treatment of cough, fever, skin diseases, snake bite, anemia and inflammation. The juice of fresh tips of young branches is instilled in case of otitis (Dutta and Dutta, 1998; Nehete $\boldsymbol{e t}$ al., 2010).

Moreover, Costus speciosus was indicated in the case of abortion, anasarca , anemia, arthrosis, asthma, bite, bleeding, blister, bronchosis, burn, cancer, catarrh, childbirth, cholera, cold, constipation, cough, cramp, dermatosis, dysentery, dyspepsia, fever, gastrosis, gravel, headache, hematuria, hiccup, inflammation leprosy, lumbago, malaria, ophthalmia, osteosis, pain, phthisis, pneumonia, rabies, rheumatism, scabies, smallpox, snakebite, stomatosis, swelling, syphilis, thirst, tuberculosis, water retention and worm (Duke $\boldsymbol{e t}$ al., 2002). Recently, Revathy et al. (2014) reported that, Costus speciosus enhances insulin secretion by the islets of langerhans, enhances peripheral glucose utilization and increases serum protein levels. Wide numbers of phytochemical constituents have been isolated from the plant and should be studied more extensively for its therapeutic effects (Srivastava et al., 2011 and 2013). The successive extracts of Costus specious rhizome have revealed the presence of alkaloids, flavanoids, cardiac glycosides, saponins, sterols and tannins(Buwa and Staden, 2006; Saraf, 2010).

The main constituent is: diosgenin which is the major constituent isolated from Costus speciosus (Dasgupta and Pandey, 1970; Yanyong and Yongqing, 1981; Sulakshana et al., 2014). The maximum quantity of diosgenin reported in the stem is $0.65 \%$, in the leaves $0.37 \%$ and in the flowers $1.21 \%$ (Anonymous, 2007). Other constituents isolated are Tigogenin, dioscin, gracillin $\beta$-sitosterol glucoside (Gupta $\boldsymbol{e t}$ al., 2008). In addition, Hansel $\boldsymbol{e t}$ al. (1994) elucidated that, the most active compounds present in Costus specious rhizome are Steroid saponins (1 to 4\%): chief components dioscin and gracillin, aglycones diosgenin, tigogenin; Steroids: sterols, including beta-sitosterol, beta-sitosterol glucoside and_Curcuminoids (3\%): including curcumin.

Diosgnin is extensively used as a raw material for the synthesis of important drugs such as corticosteroids and oral contraceptives. The rhizomes of Costus speciosus (Koen) Sm are well known for their diosgnin content and also for several saponine (Singh and Thakur, 1982). In addition, Khare (2007) reported that, all parts of the costus plant yield steroidal sapogenin, diogenin (quantity varies from 0.32 $4.0 \%)$.

It has been reported that, Costus speciosus has many antimicrobial agents against different bacteria such as Escherichia coli, Salmonella enterica and Staphylococcus aureus (Francis et al., 2002; Chen et al., 2008; Duraipandiyan et al., 2012). Ariharan et al. (2012) evaluated Costus speciosus for antibacterial activity against pathogenic strains of Gram positive (Staphylococcus aureus, Staphylococcus epidermidis) and Gram negative (Escherchia coli, Pseudomonas aeruginosa, Salmonella typhimurium) bacteria.

Moreover, Malabadi (2005) explained that the hexane, methanol and aqueous extracts of leaf and rhizomes of $C$. speciosus were used for its antibacterial activities against pathogens isolated from infected burn patients (Shigella, Staphylococcus aureus, Escherichia coli, Klebsiella pneumoniae, Pseudomonas, Bacillus subtilis and Salmonella). No antibacterial activity was recorded with water extracts. The disc-diffusion method showed significant zone of lysis against all the pathogens studied. The in vitro antibacterial activity was performed against a few pathogens viz. E. coli, Staphylococcus aureus, Klebsiella pnuemoniae and Pseudomonas aeruginosa (Saraf, 2010).

Al-Kattan (2009) indicated that, Costus speciosus of India (lute), has an antimicrobial activity against microorganisms that infect the respiratory tract, including fungi viz. A.niger, A.fumigatus and yeast viz. Candida albicans, so in accordance it can be used especially in the treatment of respiratory diseases of microbial origin.

Recently, Qiu et al. (2011) elucidate the effects of subinhibitory concentrations of costus oil on virulence factor production in Staphylococcus aureus. The data suggested that, costus oil may deserve further investigation for its potential therapeutic value in treating Staph. aureus infections.

\section{Materials \&Methods}

\subsection{Media Used}

- Nutreint Agar Medium (NAM) (HiMedia, India). It was prepared as manufacturer's direction.

- Czapek Dox Agar (g/l). (Czapek's , 1902 and Dox, 1910). It was used as basal medium in physiological studies.

\subsection{Types of Costus speciosus rhizome used}

Two types of costus plant rhizomes were obtained from druggist in Al-Madina Al-Munawarah, KSA; one is known as Qust Hindi and the other is known as Qust Bahari.

\subsection{Test organisms used:}

MRSA, I3; E.coli, I5 and Candida albicans were previously isolated by Abo-Shadi et al. (2010) and Sidkey et al. (2011) from cases with post cesarean wound infections, Department of Maternity and Children, King Fahd Hospital, Al Madinah Al Munawarah, KSA.

\subsection{Extraction of Plant Material}

Aqueous extraction and methanolic extraction of plant material was carried out according to the method described by Nair et al. (2005) with some modifications.

\section{Volume 4 Issue 11, November 2015}




\section{International Journal of Science and Research (IJSR) \\ ISSN (Online): 2319-7064 \\ Index Copernicus Value (2013): 6.14 | Impact Factor (2014): 5.611}

\subsubsection{Aqueous extraction}

The costus rhizomes were washed thoroughly under running tap water and then oven-dried at a temperature of $40-57^{\circ} \mathrm{C}$ for 5 hours. After that, the rhizomes were crushed and blended into powder using an electric blender; only $50 \mathrm{~g}$ was added to $150 \mathrm{ml}$ of distilled water (1:3) and soaked for 24 hour. Then, slurry is filtered, the filtrate was centrifuged (approximately 5000-8000 $\mathrm{rpm}$ ) for 5-10 $\mathrm{min}$ for clarification. The supernatant was collected and divided into two parts, part was left at $4^{\circ} \mathrm{C}$, and the other part was autoclaved at $121^{\circ} \mathrm{C}$ and $15 \mathrm{lbs}$ pressure and then stored at $4^{\circ} \mathrm{C}$. The final concentration of the aqueous extract was ( $1 \mathrm{~g} / 3 \mathrm{ml}, \mathrm{w} / \mathrm{v})$ (Nair et al., 2005).

\subsubsection{Methanolic extraction}

Air-dried powdered plant material (50gm) was soaked in 150 $\mathrm{ml}$ of $95 \%$ methanol (1:3) and kept for 24 hour. Plant extract was filtered through muslin cloth and centrifuged at 5000$8000 \mathrm{rpm}$ for 5-10 min. The supernatant was collected and the solvent was evaporated. It was stored at $4{ }^{\circ} \mathrm{C}$ in dark airtight bottle for further studies (Nair et al., 2005).

\subsection{Antimicrobial activity of Costus speciosus rhizome extract against MRSA, $I_{3}$}

A loopfull of 24 hour of MRSA, $\mathrm{I}_{3}$ was inoculated in $5 \mathrm{ml}$ sterile saline solution and was adjusted to $28 \times 10^{7}(\mathrm{cfu} / \mathrm{ml})$, $10 \mu \mathrm{l}$ was seeded in conical flask contains $100 \mathrm{ml}$ nutrient agar medium at $45^{\circ} \mathrm{C}$. The inoculated medium was poured into sterile Petri dishes. The assay was performed using diffusion method according to Kavenagh (1972).

\subsection{Determination of the MIC of Costus speciosus rhizome extract against MRSA, $I_{3}$}

The Minimum Inhibitory Concentration (MIC) was determined according to Drummond and Waigh (2000). Different concentrations of sterile Costus speciosus rhizome extract in sterile distilled water $(\mathbf{1 0 0} / \mathbf{0}, \mathbf{5 0 / 5 0}, \mathbf{2 5} / \mathbf{7 5}$, 12.5/87.5, 6.5/95.5 and 0/100) were tested against MRSA, $\mathrm{I}_{3}$. The mean diameter of inhibition zone measured in $\mathrm{mm}$.

2.7. Parameters controlling the growth of MRSA, $I_{3}$ in relation to aquous Costus speciosus (Hindi) rhizome extract

The following parameters were carried out to maximize the antimicrobial effect of costus extract against MRSA, $\mathrm{I}_{3}$. After determining each parameter, the best result was applied in the subsequent parameters. Triplicates were used for each particular parameter. The antimicrobial activity was assayed. The mean diameter of inhibition zone as well as standard deviation was calculated.

\subsubsection{Incubation Temperature}

In this respect, aquous Costus speciosus rhizome extract was incubated at different temperatures $\left(0,30,40,70 \& 100{ }^{\circ} \mathrm{C}\right)$ at different incubation periods (2, 6, 12 and $24 \mathrm{hr}$.), also autoclaving of extract at $121^{\circ} \mathrm{C}$ was carried out. This experiment was constructed to study thermal stability of Costus speciosus rhizome extract.

\subsubsection{Initial pH's}

Aquous Costus speciosus rhizome extract was incubated at different $\mathrm{pH}$ 's $(1,3,5,7,9$ and 13) for several time intervals $(1 / 2,2,6,12$ and $24 \mathrm{~h})$. This experiment was constructed to study $\mathrm{pH}$ stability of Costus speciosus rhizome extract.

\subsubsection{Dark and light}

In this experiment, sterile aquous Costus speciosus rhizome extract was exposed to dark, lab light and direct sun light for time intervals 24 and $48 \mathrm{hr}$.

\subsubsection{Static and shaking}

Sterile aquous Costus speciosus rhizome extract was subjected for shaking at $0.0,100$ and $200 \mathrm{rpm}$ for 24 and 84 hr.

\subsubsection{Different carbon sources}

This trial was aimed to determine the antimicrobial activity of aquous Costus speciosus rhizome extract in combination with different carbon sources. Carbon sources were added at $1 \%$ to crude extract. Different carbon sources were used viz. D-glucose, D-fructose, D-maltose, D-lactose, soluble starch and carboxy methyl cellulose. All carbon sources were sterilized with diethyl ether and left over night until diethyl ether was evaporated completely, then they were added to sterile aquous costus extract $(0.01 \mathrm{~g} / 1 \mathrm{ml})$.

\subsubsection{Different nitrogen sources}

For such purpose the following nitrogenous compounds were supplemented to aquous Costus speciosus rhizome extract such as sodium nitrate, sodium nitrite, ammonium nitrate, ammonium chloride, ammonium phosphate, ammonium sulphate and peptone. These nitrogen sources were added in an equimolecular amount to $\mathrm{Na} \mathrm{NO}_{3}$ that present in Dox's agar medium, and sterilized by diethyl ether as previously mentioned.

\subsubsection{Different Amino Acids}

Twenty two different amino acids were used viz. (L-Lysine$\mathrm{HCl}$, L-Arginine-HCl, DL-Histidine-HCl, L-Ornithine, LAspartic Acid, DL-Glutamic Acid, L-Serine, L-Threonine, DL-Asparagine, DL-Glutamine, L-Tyrosine, L-Glycine, DLAlanine, L-Valine, Leucine, L-Proline, L-Phenylalanine, LTryptophan, Methionine, Cysteine and L-Cystine). The amino acids were added in an equimolecular amount to that present in Dox's agar medium and sterilized by diethyl ether and added to sterile Costus speciosus rhizome extract. The antimicrobial activity was evaluated as usual.

\subsubsection{Different Metallic Ions}

Different metallic ions were used in this respect viz. $\mathrm{MnSO}_{4}$, $\mathrm{MgSO}_{4}, \quad \mathrm{ZnSO}_{4}, \quad \mathrm{NiSO}_{4}$ and $\mathrm{CuSO}_{4}$ with different concentrations: 10,50 and $100 \mathrm{ppm}$.

\subsubsection{Different Vitamins and Growth Promoters}

In this respect, different types of vitamins and growth promoters were used including thiamin, biotin, ascorbic acid, amino benzoic acid, adenosine, riboflavin, and inositol with three concentrations: 20, 50 and $100 \mathrm{ppm}$. The vitamin sources were separately sterilized by means of diethyl ether. The sterilized vitamin sources were added to sterilized aquous Costus speciosus rhizome extract under aseptic conditions. 


\section{International Journal of Science and Research (IJSR) \\ ISSN (Online): 2319-7064 \\ Index Copernicus Value (2013): 6.14 | Impact Factor (2014): 5.611}

2.7.10. Effect of crude costus plant extract on straight growth of Hordeum vulgaris coleoptiles

Hordeum vulgaris grains were socked at $28^{\circ} \mathrm{C}$ for about 3 hrs. The grains were then left to germinate at $28^{\circ} \mathrm{C}$ for $72 \mathrm{hr}$. Sections of $5 \mathrm{~mm}$ in length were cut from coleoptiles of uniform length by sterile cutter. The coleoptile sections were placed into a dish containing filter papers wetted with crude Costus speciosus rhizome extract to be tested for its biological activity with regard to growth. The dishes were then incubated for $16 \mathrm{hr}$ at $28^{\circ} \mathrm{C}$, after which measurements of the length of the sections were carried out. The coleoptiles sections were measured. The mean length of 10 coleoptile sections for each Petri dish was calculated.

2.8. Extraction, Separation and Purification of the antimicrobial substance from Costus speciosus rhizome

2.8.1. Solvent for extraction of the antimicrobial substance from Costus speciosus rhizome

Different trials of organic solvents systems were used for extraction of the antimicrobial substance from Costus speciosus rhizome powder viz.:

1-Chloroform 2-Ethyl Acetate

3-n-Butanol 4- Diethyl ether

5- Chloroform + ethyl acetate $(1: 1, \mathrm{v} / \mathrm{v})$

6- Chloroform and n-butanol (1: 1, v/v)

7- Ethyl acetate and n-butanol. (1: 1, v/v)

Five $\mathrm{ml}$ of each solvent was added to only 0.1 gm of Costus speciosus rhizome powder in a glass tube with cover, vortexes for $3 \mathrm{~min}$, and repeated for three subsequent days.

The top layer was transferred to small glass vial and about 10 $\mu l$ was spotted on TLC plate. The organic phase was collected, evaporated under reduced pressure until viscous syrup was obtained. The residual syrup was dissolved in the least amount of solvent and filtered through Whatman No.1 filter paper. The antimicrobial activity of the separated agent was evaluated.

About 500gm of Costus speciosus rhizome powder was soaked in 1.5 liter of the best solvent with intervals shaking for three days. The solvent was evaporated under reduced pressure by using a rotary evaporator. The evaporation was continued until viscous brown syrup was obtained. The syrup was tested for its antibacterial activity against MRSA, $\mathrm{I}_{3}$.

\subsubsection{Column chromatography}

A glass column of $2.5 \times 50 \mathrm{~cm}$ diameter was used for such purpose. The column was packed with silica gel (Prolabo). A glass rod was often used to stir the slurry. Once the slurry get homogenous, it was poured cautiously into the empty column and the column was left overnight until the silica gel was completely settled. One $\mathrm{ml}$ of crude viscous brown syrup extract was added onto top of the silica. The elution gradients of different solvent mixtures $(10 \mathrm{ml}$ each) were added. Thirty fractions were collected (each of $5 \mathrm{ml}$ ). Antimicrobial activity was performed for each separate fraction.

\subsubsection{Thin layer chromatography (TLC)}

Separation of the antimicrobial agents into its individual components has been carried out. Thin layer chromatography
(TLC) plates were used (aluminium sheets silica gel $60 \mathrm{~F}_{254}$ pre-coated $20 \times 20 \mathrm{~cm}$ with a layer thickness $0.2 \mathrm{~mm}$ ), E. Merck, Germany.

By using a solvent system composed of (55\% ethyl acetate: 45\% methanol: $10 \%$ butanol: $2 \%$ chloroform) which was found to be the best solvent system. Thin-layer chromatography was carried out by spotting $100 \mu \mathrm{l}$ of active fractions obtained from column chromatography on silica gel plate $10 \times 20 \mathrm{~cm}$ by means of winCATS Planar Chromatography Manager "sample application CAMAG Linomat 5". Syring size of $100 \mu$, spray gas is an inert gas, dosage speed $60 \mathrm{nl} / \mathrm{s}$. The $100 \mu \mathrm{l}$ was spotted in the form of a line with a band length of $40.0 \mathrm{~mm}$.

\subsubsection{Detection of separated zones on TLC plates}

After development of the plates in the best solvent, the plates were dried at room temperature. Separated zones were visualized in white normal light and UV at $254 \mathrm{~nm}$ and by UV at $365 \mathrm{~nm}$ (Smith and Seakins, 1976 and Balbaa et al., 1981). The antimicrobial activity against MRSA, $I_{3}$ was tested by scrapping off the separated zones and studying their activities.

\section{Results \& Discussion}

Historically, Staphylococcus aureus has been recognized as an important cause of disease worldwide. This has become a major pathogen associated with both hospital- and community-acquired infections (Panlilio et al., 1992). Moreover, S. aureus is uniquely equipped with virulence factors and defense mechanisms that could cause rapidly progressive fatal infections (Weigelt, 2007).

Methicillin-resistant Staphylococcus aureus (MRSA) strains were resistant to all $\beta$-lactam antibiotics. Moreover, MRSAs were identified soon after methicillin was introduced into clinical practice (Panlilio et al., 1992). MRSA has become a concern in hospitals worldwide because it can cause bacteremia, pneumonia, surgical site infections, and other nosocomial infections (Simor et al., 2001; Stefani and Varaldo, 2003; Cuevas et al., 2004; and Kuehnert et al., 2005).

Searching for new efficient and cost effective ways for the control of infectious diseases is necessary, as a result of increasing antibiotic resistance of microorganism to conventional drugs, (NCCLS, 2000; Kone, et al., 2004; Hidayathulla et al., 2011). In general, most of the medicinal plants are regarded as "Chemical Goldmines" (Thomas, 1997).

Historically, most of the medicinal preparations were derived from plants. There are a huge number of drugs that are developed from plants, and found to be very active against some diseases (Fabricant and Farnsworth, 2001). The use of complementary and alternative medicines has increased. This has led to enhancing the market for herbal products worldwide (Bodeker and Kronenberg, 2002).

Costus speciosus is the only species in the genus Costus that is medicinally important. Moreover, because of the diosgenin content, the genus Costus has become very valuable 


\section{International Journal of Science and Research (IJSR) \\ ISSN (Online): 2319-7064 \\ Index Copernicus Value (2013): 6.14 | Impact Factor (2014): 5.611}

(Thomas, 1997). Many different pharmacological activities are attributed to Costus speciosus like hepatoprotective, antioxidant, antidiabetic, hypolipidemic, and antimicrobial activity (Srivastava et al., 2011). Costus speciosus, serves as an important source of many therapeutically efficient chemicals, like diosgenin, steroidal saponins like prosapogenin, $\alpha \& \beta$ of dioscin, furostanol saponins like costusoside I \& J, octasanoic acid, cycloartenol and various other constituents (Srivastava et al., 2011).

The current study was concentrated on the antimicrobial activity of Costus speciosus rhizomes extract against resistant pathogenic microorganism viz. MRSA, $\mathrm{I}_{3}$ in comparison with E.coli, $\mathrm{I}_{5}$ and $C$. albicans.

3.1. Antimicrobial activity of aqueous and methanolic extract of Costus speciosus rhizome (Two Varieties)

The production of herbal drug preparations (i.e. extracts), using a variety of methods from simple traditional technologies to advanced extraction techniques is the first step in the value addition of medicinal and aromatic plants bioresources (Hanada et al., 2008). In the present investigation, extraction of Costus speciosus rhizome with methanol and water was carried out. Two variants of Qust was used viz. Qust Hindi and Qust Bahri. The resistant pathogenic isolates MRSA, $\mathrm{I}_{3}$ and E.coli, $\mathrm{I}_{5}$ showed susceptibility to aqueous extracts for both Qust Hindi and Qust Bahri. However, Candida albicans was resistant to costus plant extracts. MRSA, $\mathrm{I}_{3}$ was more susceptible than E.coli, $I_{5}$.
Aqueous extract of Qust Hindi was more effective as antimicrobial agent than Qust Bahri in the case of MRSA, $I_{3}$ and E.coli, $\mathrm{I}_{5}$. No bactericidal effect was recorded in case of E.coli, $\mathrm{I}_{5}$, and only bacteriostatic effect. A zone of bacteriostatic inhibition was noticed around a bactericidal inhibition zone with a diameter $41 \mathrm{~mm}$ for sterile and $34.5 \mathrm{~mm}$ for non sterile Qust Hindi against MRSA, $\mathrm{I}_{3}$. Qust Hindi was found to be activated after autoclaving treatment, this indicated that high temperature activate the antimicrobial activity of aqueous Qust Hindi extract (Table 1 and Fig. 1).

In view of the findings of other workers, water is almost shown as the practical solvent that used to extract activity in different ways (Thomson, 1978; Brantner and Grein, 1994). In addition, Tiwari et al. (2011) indicated that, the traditional method of treating a bacterial infection was by administering a decoction of the plant or apart there by boiling it in water.

Moreover, Hidayathulla, et al. (2011) reported that, the higher degree of solubility of the active principle in the polar solvents such as water and methanol as higher antibacterial activity was recorded in the polar solvent extracts compared to the non polar solvent extracts.

Based on the findings of a number of studies, Costus speciosus has many antimicrobial agents against different bacteria such as Escherichia coli, Salmonella enterica and Staphylococcus aureus (Francis et al., 2002; Chen et al., 2008; Thambi and Shafi, 2015)

Table 1: Antimicrobial activity of sterile and non sterile aqueous extract of Costus speciosus rhizome (two variants) against test organisms

\begin{tabular}{|c|c|c|c|c|c|}
\hline \multirow{2}{*}{ Test organisms } & \multirow{2}{*}{ State } & \multicolumn{4}{|c|}{ Inhibition Zone (mm) } \\
\cline { 2 - 5 } & & $\begin{array}{c}\text { Q.H } \\
\text { (Sterile) }\end{array}$ & $\begin{array}{c}\text { Q.H } \\
\text { (Non sterile) }\end{array}$ & $\begin{array}{c}\text { Q.B } \\
\text { (Sterile) }\end{array}$ & $\begin{array}{c}\text { Q.B } \\
\text { (Non sterile) }\end{array}$ \\
\hline \multirow{2}{*}{ MRSA, $\mathrm{I}_{3}$} & Bactericidal & $22 \pm 0.28$ & $15.5 \pm 0.07$ & $16 \pm 0.07$ & $15 \pm 0.07$ \\
\hline \multirow{2}{*}{ E.coli, $\mathrm{I}_{5}$} & Bacteriostatic & $41 \pm 0.14$ & $34.5 \pm 0.65$ & $36 \pm 0.14$ & $35.5 \pm 0.21$ \\
& Bactericidal & - & - & - & - \\
\hline \multirow{2}{*}{ C. albicans } & Bacteriostatic & $31 \pm 0.0$ & $27 \pm 0.07$ & $28 \pm 0.07$ & $29 \pm 0.14$ \\
\hline
\end{tabular}

Where the diameter of cork borer $=11 \mathrm{~mm}$

Q.H= Qust Hindi Q.B= Qust Bahri - = No inhibition zone

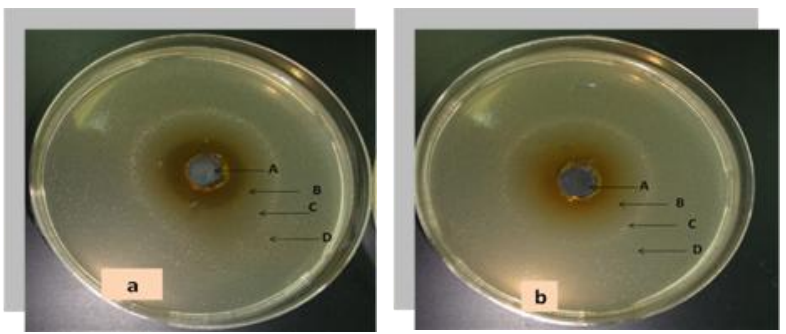

Figure (1): Antimicrobial activity of both (a) sterile and (b) non sterile aqueous extract of Qust Hindi on MRSA, $I_{3}$. (b)

A: Qust Hindi (sterile by autoclaving (a) and non sterile

B: Bactericidal Zone C: Bacteriostatic Zone D:MRSA, $\mathrm{I}_{3}$ growth

Moreover, in complete accordance with our results, Saraf (2010) and Swarnkar and Katewa (2009) indicated that, the aqueous extracts of Costus speciosus only appear to have antibacterial activity against Staphylococcus aureus.

Table 2: Antimicrobial activity of methanolic extract of Costus speciosus rhizome (two variants) against test organisms

\begin{tabular}{|c|c|c|c|}
\hline \multirow[b]{2}{*}{$\begin{array}{c}\text { Test } \\
\text { organisms }\end{array}$} & \multirow[b]{2}{*}{ State } & \multicolumn{2}{|c|}{ Inhibition Zone (mm) } \\
\hline & & $\begin{array}{c}\text { Methanolic } \\
\text { ex of Q.H }\end{array}$ & $\begin{array}{c}\text { Methanolic ex } \\
\text { of Q.B }\end{array}$ \\
\hline \multirow{2}{*}{$\mathrm{MRSA}_{3} \mathrm{I}_{3}$} & Bcateriocidal & $14.5 \pm 0.07$ & - \\
\hline & Bacteriostatic & $35.5 \pm 0.07$ & $24.5 \pm 0.07$ \\
\hline \multirow[t]{2}{*}{ E. coli, $\mathrm{I}_{5}$} & Bactericidal & - & \\
\hline & Bacteriostatic & $30.5 \pm 0.21$ & $27 \pm 0.07$ \\
\hline \multirow[t]{2}{*}{ C. albicans } & Bactericidal & - & - \\
\hline & Bacteriostatic & - & - \\
\hline
\end{tabular}

Where the diameter of cork borer $=11 \mathrm{~mm}$

Q.H= Qust Hindi Q.B= Qust Bahri - = No inhibition zone 


\section{International Journal of Science and Research (IJSR) \\ ISSN (Online): 2319-7064 \\ Index Copernicus Value (2013): 6.14 | Impact Factor (2014): 5.611}

Data represented in table (2) showed that, a bactericidal and bacteriostatic effects were exhibited in case of methanolic extract of Qust Hindi against MRSA, $\mathrm{I}_{3} \quad(14.5 \mathrm{~mm}$ and $35.5 \mathrm{~mm}$, respectively). Moreover, in terms of methanolic extract of Qust Hindi against E.coli, $\mathrm{I}_{5}$ only bacteriostatic effect was obtained. In addition, no inhibition zone detected in the case of methanolic extract of Qust Bahri with E.coli, $\mathrm{I}_{5}$. When Candida albicans was studied, no inhibition zone was detected with both variants. In fact, the weakened effect of methanolic extract compared with aqueous extract of Qust may be explained by the presence of other constituents extracted with methanol exerting anatagonistic effects or negating the positive effects of the bioactive agents, or it may be the solvent used is not the appropriate one. Cowan (1999) reported that, most commonly used solvents were ethanol and methanol, both used as initial extractants in approximately $35 \%$ of the studies. However, ethanol and methanol may not have the greatest sensitivity in producing antimicrobial chemicals on an initial screening.

Vijayalakshmi (2008) revealed that methanolic extract of costus speciosus rhizomes possess antioxidant and antimicrobial activity.

\subsection{Determination of MIC of the antimicrobial agent of aqueous Costus spicuosus rhizome (Qust Hindi) extract against the growth of MRSA, $I_{3}$}

Results illustrated in Table (3) showed the minimum inhibitory concentration (MIC) of aqueous Costus spicuosus rhizome extract (Qust Hindi) against the growth of MRSA, $\mathrm{I}_{3}$. Data declared that, inhibition zone increased by elevating the concentration of the extract. The minimum inhibitory concentration was $(166 \mathrm{mg} / \mathrm{ml})$ against MRSA, $\mathrm{I}_{3}$.

Table 3: Minimum inhibitory concentration (MIC) of aqueous Costus speciosus rhizome (Qust Hindi) extract against MRSA,

\begin{tabular}{|c|c|}
\multicolumn{2}{c}{$\mathrm{I}_{3}}$. \\
\hline $\begin{array}{c}\text { Costus speciosus rhizome } \\
\text { extract }(\mathrm{mg} / \mathrm{ml})\end{array}$ & $\begin{array}{c}\text { Inhibition zone } \\
(\mathrm{mm})\end{array}$ \\
\hline 333 & $22.25 \pm 0.28$ \\
\hline 166 & $16.5 \pm 0.07$ \\
\hline 83 & 0 \\
\hline 41.5 & 0 \\
\hline 20.8 & 0 \\
\hline 0.0 & 0 \\
\hline
\end{tabular}

\subsection{Parameters controlling the growth of MRSA, $I_{3}$ by aqueous Costus speciosus rhizome (Qust Hindi) extract}

For the purpose of improving the activity of aqueous extract of Costus speciosus rhizome as an antimicrobial agent, different parameters were studied.

Results recorded in Table (4) showed that, by increasing the incubation temperature of aqueous extract of Qust Hindi up to 40,50 and $70^{\circ} \mathrm{C}$, the antimicrobial activity against MRSA, $\mathrm{I}_{3}$ does not affected or it may be fluctuated. But, at $100^{\circ} \mathrm{C}$, the antimicrobial activity against MRSA, $\mathrm{I}_{3}$ increased with time. The same result was obtained with autoclaving. This may be due to the antimicrobial agents obtained from Qust Hindi stimulated by heat.
Table 4: Antimicrobial activity of aq. Costus speciosus rhizome (Qust Hindi) extract against MRSA, $\mathrm{I}_{3}$ in relation to different incubation temperatures and time intervals

\begin{tabular}{|c|c|c|c|c|c|}
\cline { 2 - 6 } \multicolumn{1}{c|}{} & \multicolumn{5}{c|}{ Antimicrobial activity (mm) } \\
\cline { 2 - 6 } \multicolumn{1}{c|}{} & \multicolumn{5}{c|}{ Time intervals (h.) } \\
\hline Temp. $\left({ }^{\circ} \mathrm{C}\right)$ & $1 / 3$ & 2 & 6 & 12 & 24 \\
\hline 0 & & $35.3 \pm 0.09$ & $35.3 \pm 0.09$ & $35.3 \pm 0.09$ & $35.3 \pm 0.09$ \\
\hline 30 & & $34 \pm 0.28$ & $34 \pm 0.14$ & $35 \pm 0.141$ & $39 \pm 0.141$ \\
\hline 40 & & $35 \pm 0.14$ & $35 \pm 0.07$ & $35.5 \pm 0.21$ & 34.50 .07 \\
\hline 70 & & $38 \pm 0.0$ & $36 \pm 0.14$ & $35.0 \pm 0.07$ & $36 \pm 0.0$ \\
\hline 100 & & $39.5 \pm 0.07$ & $39.5 \pm 0.07$ & $41 \pm 0.141$ & $41.5 \pm 0.21$ \\
\hline $\begin{array}{c}\text { Autoclaving } \\
121^{\circ} \mathrm{C}\end{array}$ & $41 \pm 0.14$ & & & & \\
\hline
\end{tabular}

From the historical point of view the traditional method of treating a bacterial infection was by administering a decoction of the plant or apart there by boiling it in water (Saraf, 2010).

On the other hand, the effect of different $\mathrm{pH}$ 's on the antimicrobial activity of aqueous extract of Qust Hindi against MRSA, $\mathrm{I}_{3}$ was tested, the results revealed that $\mathrm{pH} 5$ (the original $\mathrm{pH}$ of Qust Hindi) gave the least results. The acidic and alkaline $\mathrm{pH}$ exhibited activation in the antimicrobial activity of Qust Hindi against MRSA, I ${ }_{3}$ (Table 5). No available literature was found concerning this point.

Table 5: Antimicrobial activity of aqueous Costus speciosus extract (Qust Hindi) against MRSA, $\mathrm{I}_{3}$ in relation to different $\mathrm{pH}$ 's and time intervals

\begin{tabular}{|c|c|c|c|c|}
\hline \multirow{3}{*}{$\mathrm{pH}$} & \multicolumn{4}{|c|}{ Antimicrobial activity (mm) } \\
\cline { 2 - 5 } & 2 & 6 & 12 & 24 \\
\cline { 2 - 5 } & 2 & $42.5 \pm 0.07$ & $42 \pm 0.28$ & $40 \pm 0.0$ \\
\hline 1 & $39.5 \pm 0.07$ & $44 m e$ intervals (h) \\
\hline 3 & $41.5 \pm 0.07$ & $44.5 \pm 0.07$ & $45 \pm 0.0$ & $44 \pm 0.14$ \\
\hline 5 & $40 \pm 0.0$ & $40 \pm 0.0$ & $40 \pm 0.0$ & $40 \pm 0.0$ \\
\hline 7 & $44.5 \pm 0.07$ & $45 \pm 0.0$ & $45 \pm 0.0$ & $44.5 \pm 0.07$ \\
\hline 9 & $44 \pm 0.14$ & $45.5 \pm 0.0$ & $45 \pm 0.0$ & $45 \pm 0.0$ \\
\hline 13 & $45.5 \pm 0.21$ & $45 \pm 0.0$ & $45.5 \pm 0.21$ & $44 \pm 0.14$ \\
\hline
\end{tabular}

Concerning the effect of dark and light on aqueous extract of Qust Hindi against MRSA, $\mathrm{I}_{3}$, laboratory light and direct sun light showed more activation in the antimicrobial activity comparing with dark (Fig. 2). Direct sun light gave the highest antimicrobial activity, this may be due to heat radiation of sun.

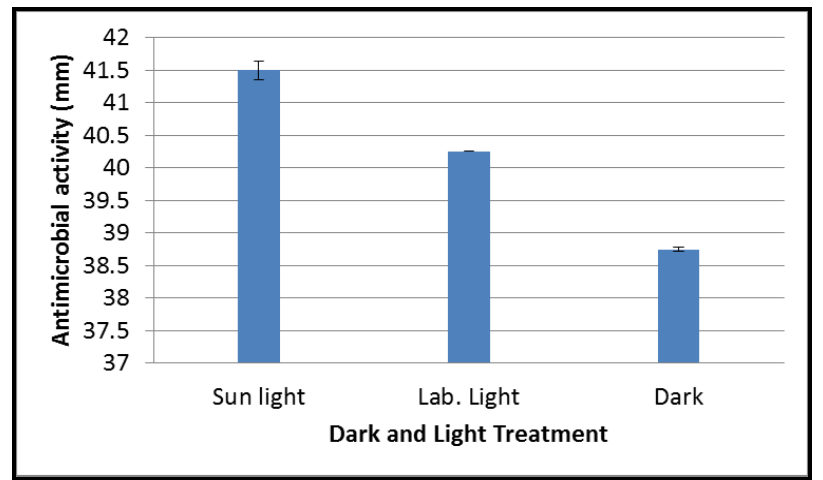

Figure 2: Antimicrobial activity of aqueous Costus speciosus extract (Qust Hindi) against MRSA, $\mathrm{I}_{3}$ in relation to dark and light 


\section{International Journal of Science and Research (IJSR) \\ ISSN (Online): 2319-7064 \\ Index Copernicus Value (2013): 6.14 | Impact Factor (2014): 5.611}

Also, increased the shaking up to $200 \mathrm{rpm}$ of aqueous extract of Qust Hindi showed pronounced antimicrobial activity against MRSA, $\mathrm{I}_{3}(43.25 \mathrm{~mm})$. This may be due to shaking could facilitate the release of the active substance in the water (Fig. 3).

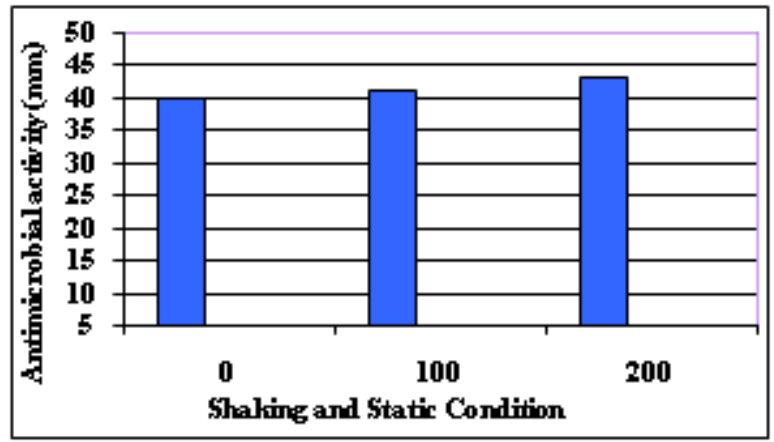

Figure 3: Antimicrobial activity of aqueous Costus speciosus extract (Qust Hindi) against MRSA, $\mathrm{I}_{3}$ in relation to shaking and static

In the present investigation, different carbon sources were used in order to determine the best one which increased the antimicrobial activity of aqueous extract of Qust Hindi against MRSA, $\mathrm{I}_{3}$. Results represented graphically in fig.(4) showed that, lactose, and carboxy methyl cellulose (CMC) exhibited the highest antimicrobial activity against MRSA, $\mathrm{I}_{3}$. They may induce synergetic activity with costus extract. Lactose was added to aqueous costus extract in the next step.

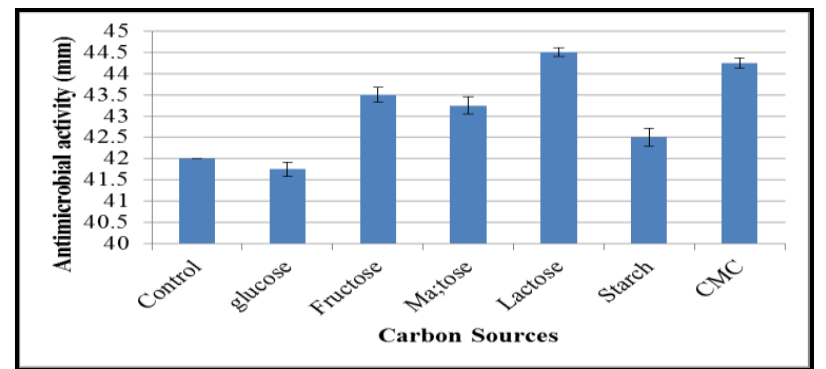

Figure 4: Antimicrobial activity of aqueous Costus speciosus extract (Qust Hindi) against MRSA, $\mathrm{I}_{3}$ in relation to different carbon sources

Data represented in Fig. (5) indicated that, none of the used nitrogen sources (organic or inorganic) induced any further antimicrobial activity against MRSA, I 3 compared with control when added to the aqueous costus plant extract. Therefore, it is suggested not to add any nitrogenous sources in combination with costus extract.

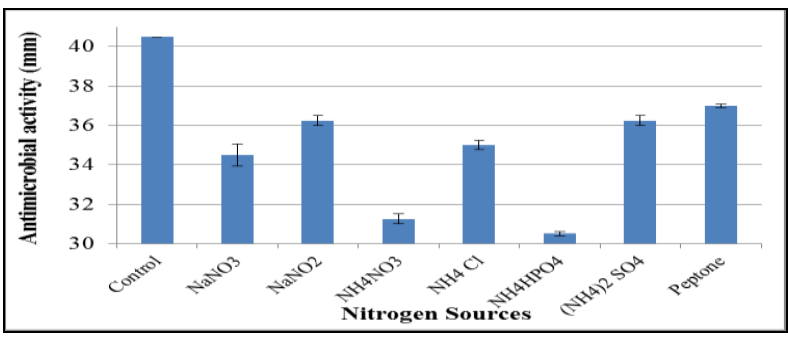

Figure 5: Antimicrobial activity of aqueous Costus speciosus extract (Qust Hindi) against MRSA, $\mathrm{I}_{3}$ in relation to different nitrogen sources
Data in fig.(6) indicated that, cysteine followed by arginine, proline and asparagine in combination with costus plant extract exhibited the highest antimicrobial activity against MRSA, $\mathrm{I}_{3}$ while, amino acids alone have no additional results compared with control.

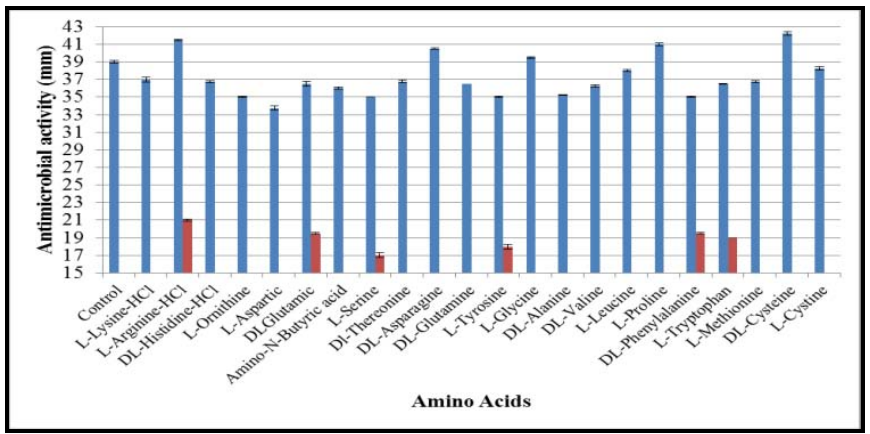

Figure 6: Antimicrobial activity of aqueous Costus speciosus extract (Qust Hindi) against MRSA, $\mathrm{I}_{3}$ in relation to different amino acids

Cysteine is a non-essential amino acid and is regarded as an important structural and functional component of many proteins and enzymes. It is also known as antioxidant agent and its antimicrobial effect has been demonstrated (Riise $\boldsymbol{e t}$ al., 1994; Gunduz et al., 2003 and Gurbuz et al., 2005). Also, according to Xiaoqian et al. (2011), cysteine has been found to inhibit biofilm formation significantly in S. aureus.

By using different metallic ions with various concentrations $(10,50 \& 100 \mathrm{ppm})$ in combination with costus extract resulted in sharply inhibition in the antimicrobial activity against MRSA, $\mathrm{I}_{3}$ comparing with control. Thus, the addition of any metallic ions must be restricted and avoided.

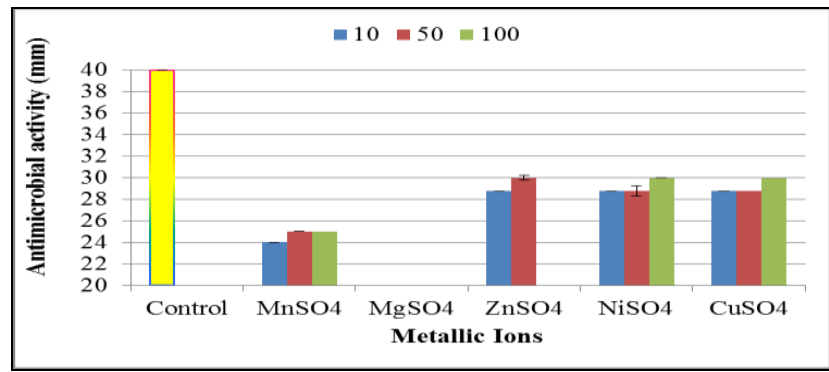

Figure 7: Antimicrobial activity of aqueous Costus speciosus extract (Qust Hindi) against MRSA, $\mathrm{I}_{3}$ in relation to different metallic ions

Data represented graphically in fig. (8) indicated that different vitamins with various concentrations in combination with costus extract had stimulatory effects on the growth of MRSA, $\mathrm{I}_{3}$. Ascorbic acid at $100 \mathrm{ppm}$ followed by biotin at $50 \mathrm{ppm}$ exhibited the highest antimicrobial activity against MRSA, $\mathrm{I}_{3}$. This finding is in agreement with the fact that ascorbic acid had efficient antimicrobial properties (Shaista et al., 2009). Ascorbic acid has been used to extend the shelf life of various fruits and vegetables (Santerre et al., 1991 and Sapers and Miller, 1995). The results in the present study are supported by the fact that ascorbic acid may enhance or stabilize the flavonoids that are responsible to disrupt the microbial membrane (Tsuchiya $\boldsymbol{e t}$ al., 1996). 


\section{International Journal of Science and Research (IJSR) \\ ISSN (Online): 2319-7064}

Index Copernicus Value (2013): 6.14 | Impact Factor (2014): 5.611

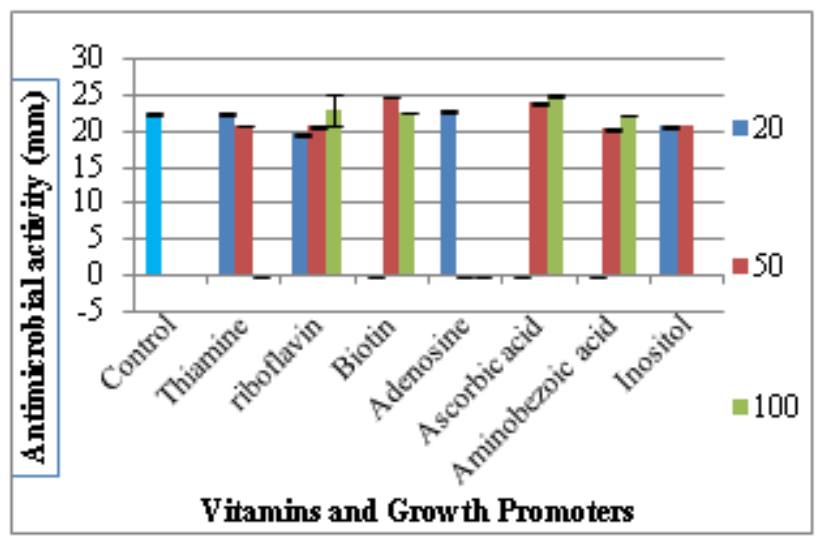

Where: Control (Costus extract +lactose + Cysteine)

Figure 8: Antimicrobial activity of aqueous Costus speciosus extract (Qust Hindi) against MRSA, $\mathrm{I}_{3}$ in relation to different vitamins.

One possible therapeutic approach could be to add ascorbic acid, to appropriate antimicrobial agents, which could work synergistically with the antimicrobial agents against pathogenic resistant microorganisms (Cursino et al., 2005). Amabile-Cuevas and Heinemann (2004) suggested that high doses of ascorbic acid in combination with antimicrobial agents may stimulate the loss of $\mathrm{R}$ plasmids and affect the levels of antibiotic resistance in Staphylococcus.

\subsection{Separation \& purification of the active antimicrobial substance from costus speciosus rhizome}

In the present investigation, the main focus was to provide a more standardized extraction method for the extraction of the antimicrobial agent from costus plant rhizome. Among all the tested solvents, ethyl acetate was the best solvent of extraction. The inhibition zone of ethyl acetate extract against MRSA, $I_{3}$ was $21 \mathrm{~mm}$ (Table 6 and Fig. 9).

Cooper and Kronenberg (2009) reported that methods used in extraction of the plant material can influence the chemical composition of the extracts and potentially the biological activity is not new. The more information on the product that is provided in research, the greater will be the ability to compare among studies and understand differences in results that may emerge. In addition, Thomas (2003) reported that, when screening a material contains an active compound, the problem becomes one of extraction, purification and assessment of the pharmacological activity.

Eloff (1998) ranked of the solvents which are reported in the literatures with the highest frequency for the extraction and their ability to solubilize antimicrobials from plants, and the ease of removal of solvent from the fraction. The author ranked them in the order of methylene dichloride, methanol, ethanol, and water.

Recently, Nehete et al. (2010) indicated that, the dried rhizomes of Costus spicuosus were grounded and subjected to successive extraction using Soxhlet apparatus. Petroleum ether (60:80), cyclohexane, benzene, ethyl acetate, chloroform, acetone, methanol and water were significantly applied for extractions used in sequence.
In addition, Binny et al. (2010) reviewed that, the ethanolic extract of the rhizome of Costus speciosus possesses antiinflammatory and antipyretic properties. Moreover, Verma and Khosa (2009) evaluated the effect of alcoholic extracts of Costus speciosus rhizomes. Costus speciosus hexane extract and its compounds have an antihyperglycemic action, and are able to ameliorate the diabetic state, representing as an alternate therapy for diabetes (Eliza $\boldsymbol{e t}$ al., 2010).

Furthermore, Niño et al. (2011) suggested that the $n$-hexane extract from Costus speciosus is a great natural antioxidant (antioxidant activity 48\%), and this activity could be explained based on its saponin contents, according to the phytochemical screening.

Table 6: Extraction of antimicrobial substance from costus speciosus rhizome by different solvent systems

\begin{tabular}{|l|c|}
\hline \multicolumn{1}{|c|}{ Solvent Used } & $\begin{array}{c}\text { Antimicrobial activity in } \\
\text { terms of mean diameter } \\
\text { of inhibition zones }(\mathrm{mm})\end{array}$ \\
\hline 1- Chloroform & 0.0 \\
2- Ethyl Acetate & $21.0 \pm 0.0$ \\
3- n-Butanol & 0.0 \\
4-Diethyl ether & 0.0 \\
5- Chloroform + ethyl acetate & $12.0 \pm 0.0$ \\
6- Chloroform $+\mathrm{n}$-butanol & 0.0 \\
7- Ethylacetate $+\mathrm{n}$ - butanol & 0.0 \\
\hline
\end{tabular}

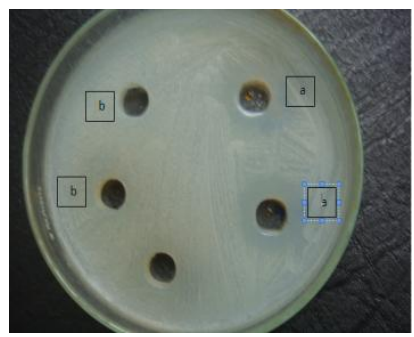

Plate (9): Antimicrobial activity of Costus speciosus rhizome powder against MRSA, $\mathrm{I}_{3}$ (a) extracted with ethyl acetate and (b) ethyl acetate disc as a control

In the present investigation, the antimicrobial substance was purified by column chromatography packed with silica gel and the eluting solvent was composed of ethyl acetate, methanol and butanol in gradient manner. Thirty fractions were collected and each was $5 \mathrm{ml}$. All fractions were tested against the target organism MRSA, $\mathrm{I}_{3}$ by using agar diffusion method. Concerning the active fractions eluted from the column chromatography, fractions $3,4,5,6,7,8, \& 9$ were found the most active fractions. Fractions $7 \& 8$ exhibited the highest antimicrobial activity with 28.6 and $27.25 \mathrm{~mm}$, respectively. On the other hand, fractions 1, 2 and 10-30 didn't exhibit any antimicrobial activity. Moreover, most of the active fractions showed different colors, from dark yellow to deep brown color (Fig 10, 11, 12 \& 13).

In view of the findings of other workers, column chromatography packed with silica gel and an eluting solvents composed of various ratios of solvent system was used to fractionation of the crude extract into active fractions (Kumigiri et al., 1996; Tabata et al., 1997; Imnagaki et al., 1998; Momose et al., 2001; El-Henawy, 2006; ElTantawy, 2008 and Khalifa et al., 2008). 


\section{International Journal of Science and Research (IJSR) \\ ISSN (Online): 2319-7064}

Index Copernicus Value (2013): 6.14 | Impact Factor (2014): 5.611

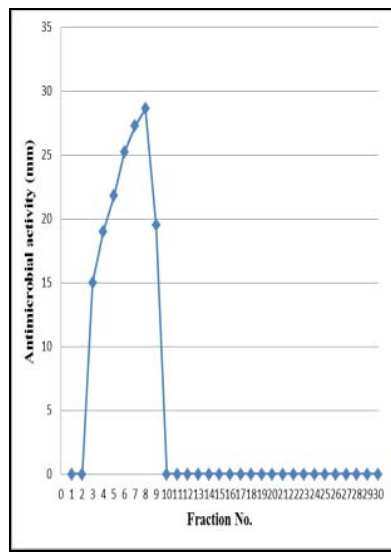

Figure 10: Fractionation pattern of active antimicrobial substances from Costus speciosus rhizome and their effect against MRSA, $\mathrm{I}_{3}$.

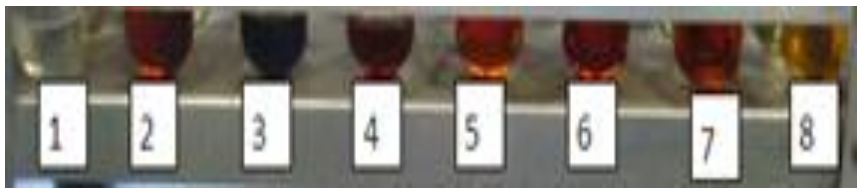

Figure 11: Colored separated active fractions, 3-9
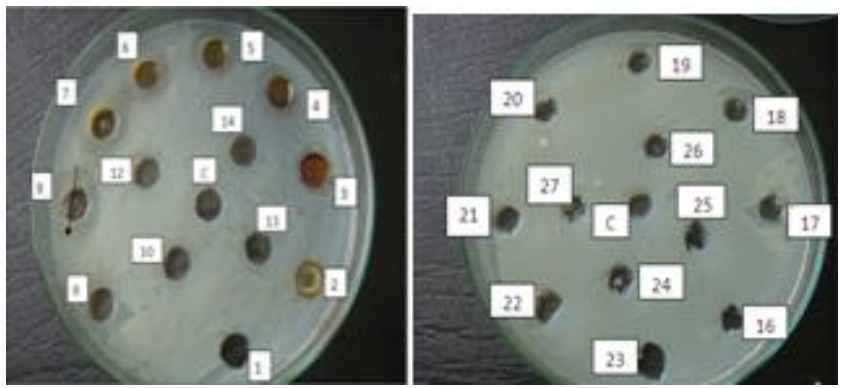

Plates (12\&13): Antimicrobial activity of column chromatography separated fractions and their effect against MRSA, I 3 , where 3,4,5,6,7,8 \&9, are the separated active fractions, and $\mathrm{C}$ is control (ethyl acetate).

The active fractions were applied on TLC plates in a trial to separate the active substances, the eluting solvent system was composed of $55 \%$ ethyl acetate: $45 \%$ methanol : $10 \%$ Butanol: $2 \%$ Chloroform. In all active fractions, only two areas were obtained; the first gave pale yellow color under normal lab light and pale fluorescent turquoise color under long wave length; the second gave dark yellow color under both normal lab light and long wave length (dominate in fractions $7 \& 8$ ). These two colored areas were detected in all active fractions, so it may play a role in the antimicrobial activity. The active fraction I exhibited antimicrobial activity against the test organism under study MRSA, $\mathrm{I}_{3}$ and gave $25.5 \mathrm{~mm}$, while fraction II gave $16.25 \mathrm{~mm}$. (Table 7 and Fig. 14).

Table 7: Antimicrobial activity of the active fractions against MRSA, $\mathrm{I}_{3}$.

\begin{tabular}{|c|c|c|c|}
\hline \multirow{2}{*}{$\begin{array}{l}\text { Active } \\
\text { fractions }\end{array}$} & \multicolumn{2}{|c|}{ Colour } & \multirow{2}{*}{$\begin{array}{l}\text { Antimicrobial activity } \\
\text { in terms of mean } \\
\text { diameter of inhibition } \\
\text { zones }(\mathrm{mm}) \\
\end{array}$} \\
\hline & $\begin{array}{c}\text { Normal lab } \\
\text { light }\end{array}$ & $\begin{array}{l}\text { Long wave } \\
\text { length }\end{array}$ & \\
\hline I. & & $\begin{array}{c}\text { pale fluorescent } \\
\text { turquoise }\end{array}$ & 25.5 \\
\hline II. & dark yellow & dark yellow & 16.25 \\
\hline
\end{tabular}

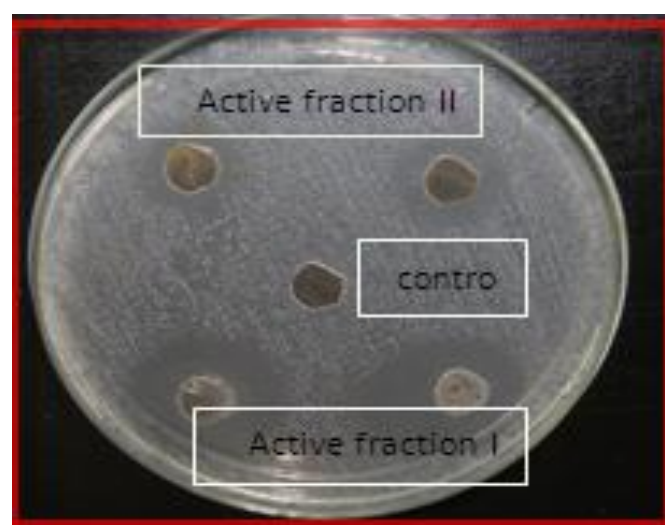

Plate (13): Antimicrobial activity of the active fractions against MRSA, $\mathrm{I}_{3}$.

Although this data may be very important in probing of biochemistry of this plant in the future, there is a need to further carry out spectroscopic studies in order to elucidate the structure of these compounds.

Costus speciosus are known to contain saponins and sapogenins, costusoside I \& J, dioscin, dioscin prosapogenin A \& B, protodioscin, diosgenin and diosgenin derivatives, gracillin, tigogenin, cadinene, carvacrol, 1,8-cineol, methyl ester paracoumaric acid, cycloartanol, cycloartenol, 31norcycloartanone, cycloaudenol, lanosterol, daucosterol, beta-sitosterol, stigmasterol, lipids, lauric acid, linoleic acid, myristic acid, oleic acid, palmitic acid, stearic acid, plastoquinone, and vanillic acid (WHO, 2009). Recently, Borkataky et al. (2014) reported that, the rhizome of Costus speciosus is a source of secondary metabolites like phenolics, flavonoids, tannins, saponins, steroids and glycosides which are reported for various biological effects including antimicrobial and antioxidant activities.

Recently, the oil was found to be active against four Gram positive bacteria namely Staphylococcus aureus, Bacillus subtilis, Streptococcus faecalis, and Staphylococcus albus and Gram negatives namely E.coli, Pseudomonas aeruginosa, Klebsiella aerogenes and Protieus vulgaris. The activity may be due to the presence of individual components like $\alpha$-Humulene and Zerumbone or due to the synergistic effect of the major and minor components (Thambi and Shafi, 2015).

In conclusion, an attempt has been made to evaluate one of the medicinal plants that have attracted considerable global interest in recent years. From the thorough study and investigation of the available literature on Costus speciosus, it is clearly found that the extract possess compounds with antimicrobial properties and serves as an important source for treating diseases caused by Methicillin-resistant Staphylococcus aureus (MRSA) strains. The rhizome of C. speciosus (Qust Hindi) has the potential for use in diet for nutritive and health benefits.

\section{References}

[1] Bukhari (1): M. Muhsin Khan, Introduction to Translation of Sahih Bukhari Volume 7, Book 71, Number 599: 


\section{International Journal of Science and Research (IJSR) \\ ISSN (Online): 2319-7064 \\ Index Copernicus Value (2013): 6.14 | Impact Factor (2014): 5.611}

[2] Bukhari (2): M. Muhsin Khan, Introduction to Translation of Sahih Bukhari Volume 7, Book 71, Number 616:

[3] Abo-Shadi, M.A.; Nagwa M. Sidkey; and Abeer M. Al-Mutrafy (2010). Antimicrobial Agent Producing Microbes from Some Soils' Rhizosphere in Al-Madinah Al-Munawwarah, KSA. Journal of American Science; 6(10): 915-925.

[4] Al-Kattan, M. O. (2009). Effect of Costus speciosus on Aspergillus niger \& A.fumigatus Fungi and Candida albicans Yeast for Respiratory System Infection. Umm Al-Qura Univ. J. App. Sci., 1 (2): pp. 40-51

[5] Amabile-Cuevas, C. F. and Heinemann J. A. (2004). Shooting the messenger of antibiotic resistance: plasmid elimination as a potential counterrevolutionary tactic. Drug Discov. Today, 9: pp. 465-467.

[6] Anonymous, (2007). The Wealth of India: Raw Materials. National Institute of Science Communication and Information Resources, CSIR, 2: pp. 211-213.

[7] Ariharan, V. N. Meena Devi, V. N., Rajakokhila, M. and Nagendra Prasad. P. (2012). Antibacterial activity of Costus speciosus rhizome extract on some pathogenic bacteria. International Journal of Advanced Life Sciences (IJALS) Volume 4: 24-27

[8] Balbaa, S. I.; Hilal, S. H. and Zaki, A. Y. (1981). Medicinal plant constituents, 3rd edition. General Agency for University and School Books.

[9] Binny, K.; Kumar, S. G. and Thomas, D. (2010). Antiinflammatory And Antipyretic Properties Of The Rhizome Of Costus speciosus (Koen.)-SM. J. Basic Clin. Pharm., 1 (3): pp. 177-180.

[10] Bodeker, G. and Kronenberg, F. (2002). Public health agenda for traditional, complementary and alternative medicine. Am. J. Publ. Health, 92 (10): pp. 1582-1591.

[11] Borkataky, M.; Kakoti, B. B.; Saikia, L.R. (2014). Analysis of Primary and Secondary Metabolite Profile of Costus speciosus (Koen Ex.Retz.) Sm. Rhizome. Journal of Natural Product \& Plant Resources; 4( 3): 71

[12] Brantner, A. and Grein, E. (1994). Antibacterial activity of plant extracts used externally in traditional medicine. J. Ethnopharmacol. 44: pp.35-40.

[13] Buwa, L. V. and Staden, J. V. (2006). Antibacterial and antifungal activity of traditional medicinal plants used against venereal diseases in South Africa. $J$. Ethnopharmacol., 105: pp. 159-142.

[14] Chen, N.; Chin Chang, C.; Chai Ng, C.; Yi Wang, C.; Tay Shyu, Y. and Liang Chang, T. (2008). Antioxidant and antimicrobial activity of zingiberaceae plants in Taiwan. Plant Foods for Human Nutrition, 63 (1): pp. 15-20.

[15] Cooper, R. and Kronenberg, F. (2009). Botanical Medicine:from bench to bedside. Mary Ann Liebert, Inc. USA.

[16] Cordell, G. A. (2000). Biodiversity and drug discovery a symbiotic relationship. Phytochemistry, 55: pp. 465480.

[17] Cowan, M. M. (1999). Plant Products As Antimicrobial Agents. Clinical Microbiology Reviews. American Society for Microbiology, 12 (4): pp. 564582.

[18] Cursino, L.; Chartone-Souza, E. and Nascimento, A. M. A. (2005). Synergic Interaction between Ascorbic Acid and Antibiotics against Pseudomonas aeruginosa.
Brazilian Archives of Biology and Technology, 48 (3): pp. 379-380.

[19] Cuevas, O.; Cercenado, E.; Vindel, A.; Guinea, J.; Sanchez-Conde, M.; Sanchez- Somolinos, M.; and Bouza, E. (2004). Evolution of the antimicrobial resistance of Staphylococus spp. in Spain: five nationwide prevalence studies, 1986 to 2002. Antimicrobial Agents Chemotherapy, 48 (11): pp. 4240 4245.

[20] Czapek's ，F. ( 1902). Untersnehengen uber die stiekstoff gewinnung und Eiweisseikdung der pflozen Beitr. Chem, Physiol. U. Pathol. 1:pp.540-560; 3: pp.4766.

[21] Deb, D. B. (1983). The Flora of Tripura State. Buddlejaceae-Gramineae (Poaceae). Today and Tomorrow's Printers and Publishers. 2.

[22] Dasgupta, B. and Pandey, V. B. (1970). A new Indian source of diosgenin (Costus speciosus). Cell. Molec. Life. Sci., 26: pp. 475-476.

[23] Drummond, A. J. and Waigh, R. D. (2000). The development of microbial methods for phytochemical screening. Recent Res. Devel. Phytochem., 4: pp. 145-152.

[24] Dox, A. W. (1910). The intracellular enzymes of Penicillium and Aspergillus with apecial reference to those of P. camemberti. U. S. Dept Agar. Bur. Animal Ind. Bull, pp. 120-170.

[25] Duke, S. O. (1991). Plant terpenoids as pesticides. In toxicology of plant and fungal compounds. Handbook of Natural Toxins, Vol. 6., R.F. Keeler and A.T. Tu, (Eds.). Marcel Dekker, New York. pp. 269-296.

[26] Duke, J. A.; Bogenschutz-Godwin, M. J.; duCellier, J. and Duke, P. K. (2002). Hand Book of Medicinal Herbs. CRC Press LLC, USA.

[27] Dutta, A. C. and Dutta, T. C. (1998). Botany. $6^{\text {th }}$ ed., Oxford University Press. p. 599.

[28] Duraipandiyan, V.; Al-Harbi, N.A.; Ignacimuthu, S. and Muthukumar, C. (2012). Antimicrobial activity of sesquiterpene lactones isolated from traditional medicinal plant, Costus speciosus (Koen ex.Retz.) Sm. BMC Complementary and Alternative Medicine, 12:13

[29] El-Henawy, S. B. (2006). Recycling of solid wastes using a safe microbiological system. M.Sc. Thesis, Microbiology Dept, Fac. of Science, Al-Azhar Univ. Cairo. Egypt.

[30] Eliza, J.; Rajalakshmi, M.; Ignacimuthu, S. J. and Daisy, P. (2010). Normalizing effects of Costus speciosus rhizome crude extracts and its fractions on diabetic complications in STZ-induced diabetic rats. Med. Chem. Res. Biomed \& Life Sci., 20 (7): pp. 11111118.

[31] Eloff, J. N. (1998). Which extractant should be used for the screening and isolation of antimicrobial components from plants? J. Ethnopharmacol., 960: pp. 1-8.

[32] El-Tantawy, N. I. (2008). The bioprocess development for the production of bioactive material (s) by actinomycetes. M.Sc. Thesis, Botany Dept, Fac. of Science, Zagazig Univ, Cairo, Egypt.

[33] Essawi, T. and Srour, M. (2000). Screening of some Palestinian medicinal plants for antibacterial activity. $J$. Ethnopharmacol., 70: pp. 545-549. 
[34] Fabricant, D. S. and Farnsworth, N. R. (2001). The value of plants used in traditional medicine for drug discovery. Environ. Health Pers., 109 (1): 69-75.

[35] Francis, G.; Kerem, Z.; Makkar, P. S. and Becker, K. (2002). The biological action of saponins in animal systems. Br. J. Nut., 88: pp. 587-605.

[36] Gupta, A. K.; Tondon, N. and Sharma, M. (2008). Quality Standards of Indian Medicinal Plants. Indian Council of Medical Research (ICMR), India. 7: p. 48.

[37] Gunduz, H.; Karabay, O.; Tamer, A.; O“ zaras, R.; Mert, A. and Fehmi, O“. (2003). Tabak N-acetyl cysteine therapy in acute viral hepatitis. World. J. Gastroenterol., 9 (2): pp. 2698-2700.

[38] Gurbuz, A. K.; Ozel, A. M.; Ozturk, R.; Yldirim, S.; Yazgan, Y. and Demirturk, L. (2005). Effect of Nacetyl cysteine on Helicobacter pylori. South. Med. J., 98 (11): pp. 1095-1097.

[39] Handa, S. S.; Khanuja, S. P. S.; Longo, G.; Rakesh, D. D. (2008). Extraction Technologies for Medicinal and Aromatic Plants. United Nations Industrial Development Organization and the International Center for Science and High Technology, Trieste, p.7

[40] Hansel, R.; Keller, K.; Rimpler, H. and Schneider, G. (1994). Hagers Handbuch der Pharmazeutischen Praxis. 5. Aufl., Bde 4 - 6 .Drogen, Springer Verlag Berlin, Heidelberg, New York.

[41] Hidayathulla, S.; Chandra, K. and Chandrashekar, K. R. (2011). Phytochemical Evaluation and Antibacterial Activity of Pterospermum Diversifium Blume. Int. J. Pharm. Pharm. Sci., 3 (2): p. 166.

[42] Imnagaki, T.; Kaneda, K.; suzuki, Y.; Hirai, H.; Nomura, E.; Sakakibara, T.; et al. (1998). CJ-12, 373, a novel topoisomerase II inhibitor: Fermentation, isolation, structure, elucidation and biological activities. J. Antibiot., 51 (2): pp. 112-116.

[43] Jigna, P.; Rathish, N. and Sumitra, C. (2005). Preliminary screening of some folklore medicinal plants from western India for potential antimicrobial activity. Ind. J. Pharmmacol., 37 (6): pp. 408-409.

[44] Kavenagh, F. (1972). Analytic Microbiology. Acad. Press, New York. 2: pp.142-181.

[45] Kayser, O. and Quax, W. J. (2007). Medicinal Plant Biotechnology, From Basic Research to Industrial Applications. WILEY-VCH Verlag GmbH \& Co. KGaA, Weinheim.

[46] Khalifa, M. A.; Haroun, B. M.; Atta, H. M.; AbulHamd, A. T. and El-Enshasy, H. (2008). Vernamycina biosynthesis by streptomyces sp-az-sh- 29: characterization, fermentation, purification and biological activities. Botany and Microbiology Dept. Faculty of science (Boys), Al-Azhar University, Cairo, Egypt.

[47] Khan, M. (2009). Qust-al-Bahri- The Magic Potion from India. 14 (159).

[48] Khare, C. P. (2007). Indian Medicinal Plants, An Illustrated Dictionary. Pub. Springer. New Delhi, India.

[49] Kone, W. M.; Atindehou, K. K.; Terreaux, C.; Hostettmann, K.; Traore, D.; and Dosso, M. (2004). Traditional medicine in north Cote - Dlovoire screening of 50 medicinal plants for antibacterial activity. $J$. Ethnopharmacol. 93: pp. 43-49.

[50] Kuehnert, M. J.; Hill, H. A.; Kupronis, B. A.; Tokars, J. I.; Solomon, S. L. and Jernigan, D. B.
(2005). Methicillin-resistant-Staphylococcus aureus hospitalizations. United States. Emerg. Infect. Dis., 11: pp. $868-872$.

[51] Kumigiri, K.; Suzuki, Y.; Shibazaki, M.; Morioka, M. and Suzuki, K. I. (1996). Kalimantacius A, B and C, novel antibiotics from Alcaligenes sp. Y1-02632s. ITaxonomy, fermentation, isolation and biological properties. J. Antibiot., 49 (2): pp. 136-139.

[52] Malabadi, R. B. (2005). Antibacterial activity in the rhizome extracts of Costus speciosus (Koen.). $J$. Phytolog. Res., 18 (1): pp. 83-85.

[53] Mandal, A. B.; Thomas, V. A. and Elanchezhian, R. (2007). RAPD pattern of mCostus speciosus Koen ex. Retz., an important medicinal plant from the Andaman and Nicobar Islands. Current Science, 93 (3): p. 10.

[54] Momose, I.; Sekizawa, R.; Hashizume, H.; Kinoshita, N.; Homma, Y ;.Hamada, Y,; et al. (2001). Typropeptins A and B, new proteasome inhibitors produced by Kitasatospora sp. MK 993-dF2. Taxonomy, isolation, Physicochemicalproperties and biological activities. J Antibiot., 54 (12 ): pp. 997-1003.

[55] Nair, R.; Kalariya, T. and Chanda, S. (2005). Antibacterial activity of some selected Indian medicinal flora. Turk. J. Biol., 29: pp. 41-47.

[56](NCCLS) National Committee for Clinical Laboratory Standards (2000). Performance standard for antimicrobial disk susceptibility test. Approved standard NCCLS document M2-A7. Wayne Pa.

[57] Nehete, J.; Bhatia, M. and Narkhed, M. (2010). In vitro evaluation of antioxidant activity and phenolic content of Costus speciosus (Koen) J. E. Smith. Iran. J. Pharma. Res., 9 (3): 271-277.

[58] Niño, J.; Correa, Y. M.; Cardona1, G. D. And Mosquera, O. M. (2011). Antioxidant and antitopoisomerase activities in plant extracts of some Colombian flora from La Marcada Natural Regional Park. Rev. Biol. Trop. Int. J. Trop. Biol., 59 (3): pp. 1089-1097.

[59] Okpuzor, J. and Oloyede, A. M. (2009). Nature and Science, 7 (8): 89-94.

[60] Pachlatko , J. P. (1998). Natural Products in Crop Production. Chimia., 52: pp. 29-47.

[61] Panlilio, A. L.; Culver, D. H.; Gaynes, R. P.: Banerjee, S.; Henderson, S.; Tolson, J. S. and Martone, W. J. (1992). Methicillin-resistant Staphylococcus aureus in U.S. hospitals, 1975-1991. Infect. Control Hosp. Epidemiol., 13: pp. 582-586.

[62] Qiu, J.; Wang, J.; Luo H.; Du, X.; Li, H.; Luo, M.; Dong, J.; Chen, Z. and Deng, X. (2011). The effects of subinhibitory concentrations of costus oil on virulence factor production in Staphylococcus aureus. .,110(1):333-340.

[63] Revathy, J.; Abdullah, S. S. and Kumar, P. S. (2014). Antidiabetic Effect of Costus Speciosus Rhizome Extract in Alloxan Induced Albino Rats. Journal of Chemistry and Biochemistry, 2(1) :13-22

[64] Riise, G. C.; Larsson, S.; Larsson, P.; Jeansson, S. and Andersson, B. A. (1994). The intrabronchial microbial flora in chronic bronchitis patients: a target for N-acetylcysteine therapy? J. Eur. Respir., 7: pp. 94-101.

[65] Santerre, C. R.; Leach, T. F. and Cash, J. N. (1991). Bisulfite alternatives in processing abrasion-peeled Russet Burbank potatoes. J. Food Sci., 56 (1): 257-259. 


\section{International Journal of Science and Research (IJSR) \\ ISSN (Online): 2319-7064 \\ Index Copernicus Value (2013): 6.14 | Impact Factor (2014): 5.611}

[66] Sapers, G. M. and Miller, R. L. (1995). Heated ascorbic/citric acid solution as browning inhibitor for pre-peeled potatoes. J. Food Sci., 60 (4): pp. 762-776.

[67] Saraf, A. (2009).

[68] Saraf, A. (2010). Phytochemical and Antimicrobial Studies of Medicinal Plant Costus Speciosus (Koen.). EJ. Chem., 7 (1): pp. 405-415.

[69] Service, R. F. (1995). Antibiotics that resist resistance. Science, 270: pp. 724-727.

[70] Shaista, J. K.; Fatima, A.; Zaidi, N. and Ejaz, N. (2009). Effect of different stabilizers on the antibacterial activity of "ginger garlic paste". J. Appl. Sci. Environ. Manage., 15 (5): pp. 105 - 109.

[71] Sidkey, N.M.; Abo-Shadi, MA.A. and Al-Mutrafy, A.M. (2011). Lincomycin B biosynthesis by Streptomyces ramulosus, A-MM-24: Fermentation, Purification and Structural Elucidation. New Egyptian Journal of Microbiology. Vol. 30, pp. 172-191

[72] Simor, A. E., Ofner-Agostini, M., Bryce, E., et al. (2001) The evolution of methicillinresistant Staphylococcus aureus in Canadian hospitals: 5 years of national surveillance. CMAJ., 165: 21-26.

[73] Singh, S. B. and Thakur, R. S. (1982). Saponins from the seeds of Costus speciosus. J. Nat. Prod., 45 (6): pp. 667-671.

[74] Smith, I. and Seakins, J. W. (1976). Chromatographic Electrophoretic techniques: Paper and thin layer chromatography. William Heinemann Medical Books, LTD, Great Britain. 1: pp. 65-137.

[75] Srivastava, S.; Singh, P.; Mishra1, G.; Jha1, K. K. and Khosa, R. L. (2011). Costus speciosus (Keukand): A review. Pelagia Research Library. Der. Pharmacia. Sinica., 2 (1): pp. 118-128.

[76] Srivastava, S.; Singh, P.; Jha, K. K.; Mishra, G. Srivastava, S. and Khosa, R. L. (2013). Antiinflammatory, Analgesic and Antipyretic Activities of Aerial Parts of Costus speciosus Koen. Indian $J$ Pharm Sci. 75(1): 83-88.

[77] Stefani, S. and Varaldo, P. E. (2003). Epidemiology of methicillin-resistant staphylococci in Europe. Clin. Microbiol. Infect., 9: pp. 1179-1186.

[78] Sulakshana, G. and Sabitha A. Rani (2014). HPLC analysis of diosgenin in three species of Costus. International Journal of Pharma Sciences and Research (IJPSR), Vol 5 No 11: 747-749

[79]Swarnkar, S. and Katewa, S. S. (2009). Antimicrobial Activities Of Some Tuberous Medicinal Plants From Aravalli Hills Of Rajasthan. J. Herbal Med. Toxicol., 5 (1): pp. 55-58.

[80] Tabata, Y.; Miike, N.; Hatsu, M.; Kurata, Y.; Yaguchi, T.; Someya, A.; et al. (1997 (. PF1092 A, B and $\mathrm{C}, \mathrm{New}$ nonsteroidal progesterone receptor ligands produced by Penicillum oblatum. Taxonomy of producing strain, fermentation, isolation and biological activities. J. antibiot., 50 (4): pp. 304-313.

[81] Tag, H.; Das, A. K. and Loyi, H. (2007). Natural Product Radiance. 6 (4): pp. 334-340.

[82] Thambi, M. and Shafi, M.P. (2015). Rhizome Essential Oil Composition of Costus Speciosus and its Antimicrobial Properties. International Journal of Pharmaceutical Research \& Allied Sciences, Volume 4, Issue 1 (2015):28-32
[83] Thomas, J. (1997). Medicinal and aromatic plants research in India. In UNDP. 1997. Proc. Training course on Industrial Exploitation of Indigenous Medicinal and Aromatic Plants. Beijing, China. 17-27 June, 1997.

[84] Thomas, G. (2003). Fundamentals of Medicinal Chemistry. Pub. John Wiley \& Sons Ltd. Great Britain.

[85] Thomson, W. A. R. (1978). Medicines from the Earth. McGraw-Hill Book Co., Maidenhead, United Kingdom.

[86] Tiwari, P.; Kumar, B.; Kaur, M.; Kaur, G., and Kaur, H. (2011). Phytochemical screening and Extraction: A Review. Internationale Pharmaceutica Sciencia. 1 (1): p. 100.

[87] Tringali, C. (2001). Bioactive Compounds from Natural Sources. Pub. Taylor \& Francis. USA.

[88] Tsuchiya, H; Sato, T. M.; Fujiwaras, S.; Tanigaki, S.; Ohyama, M.; Tanaka, T. and Linuwa, M. (1996). Comparative study on the antibacterial activity of phytochemical flavones against methicillin resistant Staphylococcus aureus. J. Ethnopharm., 50: pp. 27-54.

[89] Verma, N. and Khosa, R. L. (2009). Effect of Costus speciosus and Wedelia chinensis on BrainNeurotransmitters and Enzyme Monoamine Oxidase Following Cold Immobilization Stress. $J$. Pharm. Sci. \& Res., 1 (2): pp. 22-25.

[90] Vijayalakshmi, M. A. (2008). Screening of Costus speciosus extract for antioxidant activity. Fitoterapia, 79 (3): pp. 197-198.

[91] Weigelt, J. A. (2007). Methicillin-resistant Staphylococcus aureus (MRSA). Informa Healthcare USA, Inc.

[92] WHO (World Health Organization) (2009). Medicinal Plants In Papua New Guinea. Information On 126 Commonly Used Medicinal Plants In Papua New Guinea. Who Library Cataloguing In Publication Data.

[93] Xiaoqian, W.; Wang, Y. and Tao, L. (2011). Sulfhydryl compounds reduce Staphylococcus aureus biofilm formation by inhibiting PIA biosynthesis. Blackwell Publishing Ltd., 516: pp. 44-50.

[94] Yanyong, C. and Yongqing, Y. (1981). Zhongcaoyao, 12(11), 506, 505. 